\title{
Aplikasi Text Mining untuk Klasterisasi Aduan Masyarakat Kota Semarang Menggunakan Algoritma K-means
}

\author{
Dita Afida ${ }^{1}$, Erika Devi Udayanti ${ }^{2}$, Etika Kartikadharma ${ }^{3}$ \\ ${ }^{1}$ Sistem Informasi, Fakultas IImu Komputer,Universitas Dian Nuswantoro \\ Semarang, e-mail: ditaafida@gmail.com \\ ${ }^{2}$ Sistem Informasi, Fakultas IImu Komputer, Universitas Dian Nuswantoro \\ Semarang, e-mail: erikadevi@dsn.dinus.ac.id \\ ${ }^{3}$ Teknik Informatika, Fakultas IImu Komputer, Universitas Dian Nuswantoro \\ Semarang, e-mail: etika.kartikadarma@dsn.dinus.ac.id
}

\section{ARTICLE INFO}

Article history:

Received 11 June 2020

Received in revised form 06 July 2020

Accepted 22 January 2021

Available online 31 January 2021

\begin{abstract}
Social media is a service that is very supportive for government activities, especially in providing openness and community-based government. One form of its implementation is the Semarang City government through the Pusat Pengolalaan Pengaduan Masyarakat (P3M), whose task is to manage community complaints that enter one of the communication channels namely social media twitter. The number of public complaints that enter every day is very varied. This is certainly quite difficult for managers in categorizing complaints reports according to the relevant government organizations. This paper focuses on the problem of how to conduct clustering of community complaints. The data source comes from Twitter using the keyword "Laporhendi". Text document data from community complaint tweets was analyzed by text mining methods. This method begins with preprocessing data such as case folding, tokenizing, stemming, stopword removal and tf-idf measurement. Clustering algorithm that will be used in dividing the complaint cluster is $\mathrm{k}$-means algorithm. The evaluation of cluster results is done by using purity to determine the accuracy of the clustering.
\end{abstract}

Keywords: community complaint, text mining, kmeans algorithm, purity

\section{Pendahuluan}

Masyarakat saat ini sangat akrab dengan keberadaan teknologi informasi dan komunikasi dalam aktivitas sehari-hari, baik aktivitas berbelanja, aktivitas sosial dan termasuk aktivitas di lingkungan pemerintahan. Adaptasi teknologi di lingkungan pemerintah dilakukan untuk memenuhi kebutuhan transparansi kerja pemerintah kepada masyarakat yang tentunya tujuan utamanya adalah dalam upaya peningkatan layanan publik yang dilakukan melalui penggunaan Received June 11, 2020; Revised July 06, 2020; Accepted January 22, 2021 
teknologi informasi dan komunikasi. Saat ini pemerintah pusat hingga daerah membuka kanal komunikasi elektronik secara luas bagi masyarakat untuk dapat berbagi informasi maupun menghimpun berbagai saran maupun aduan terkait layanan pemerintah. Kanal komunikasi antara pemerintah dan masyarakat ini disediakan dalam berbagai bentuk mulai dari web yang dapat diakses masyarakat selama 24 jam, aplikasi berbasis mobile, layanan berbasis short message hingga media sosial seperti twitter, facebook hingga instagram. Masyarakat menjadi semakin mudah memperoleh informasi dan membagikan informasi kepada masyarakat lainnya melalui internet. Salah satunya adalah yang berkaitan dengan aduan masyarakat berkaitan dengan layanan pemerintahan.

Dalam penelitian ini mengambil studi kasus pada Pusat Pengolalaan Pengaduan Masyarakat (P3M) khususnya di kota Semarang. Dimana kantor P3M ini bertugas untuk melakukan pengelolaan aduan masyarakat yang masuk. Banyaknya aduan masyarakat yang masuk tiap harinya sangatlah bervariatif. Hal ini tentunya cukup menyulitkan pengelola dalam mengkategorikan laporan pengaduan masayarakat. Dalam proses pengkategorisasian aduan, bidang pelaporan harus membaca satu persatu dan tentu memahami isi dari aduan masyarakat. Baru kemudian petugas menentukan aduan tersebut ditujukan ke unit pemerintah terkait untuk tindak lanjut. Mempertimbangkan jumlah aduan yang masuk setiap harinya, tentu proses pengkategorisasian tersebut memakan banyak waktu. Hal ini membuat semakin lama pula aduan tersampaikan dan ditindak lanjuti oleh Organisasi Pemerintah Daerah (OPD) yang terkait. Dari hasil wawancara yang dilakukan dengan pihak pengelola aduan masyarakat, ada sejumlah 11 Organisasi Pemerintah Daerah yang berkaitan dengan laporhendi, diantaranya yaitu OPD PLN, Dinas Perhubungan (Dishub), Dinas Perumahan dan Kawasan Permukiman (Disperkim), Pekerjaan Umum (PU), Dinas Kesehatan (Dinkes), OPD PDAM, OPD Penanggulangan Bencana Daerah (BPBD), OPD Dinas Kependudukan Pencatatan Sipil (Dukcapil), Rumah Sakit Umum Daerah (RSUD), Satuan Polisi Pamong Praja (Satpol PP) dan terakhir OPD Dinas Lingkungan Hidup. Pengelola harus melakukan pengkategorisasian setiap aduan masyarakat yang masuk ke sejumlah OPD tersebut.

Penelitian ini fokus pada permasalahan bagaimana melakukan pengelompokkan (clustering) aduan masyarakat yang disampaikan melalui twitter. Clustering sendiri merupakan salah satu metode dalam data mining yang melakukan pemetaan terhadap sejumlah besar data menjadi klaster atau kelompok yang berbeda dan memasukkannya ke dalam klaster yang sama satu dengan yang lain dan yang berbeda dari klaster lain. Sumber data berasal dari data aduan masyarakat yang diambil dari media sosial twitter yang berupa dokumen text dengan menggunakan kata kunci atau tagar \#laporhendi. Dikarenakan data text bersifat tidak terstruktur sehingga memerlukan suatu analisis text untuk pemrosesan datanya. Text mining merupakan teknik analisis teks dalam suatu dokumen melalui kategorisasi teks, pengelompokan teks, ekstraksi konsep, dan penghapusan teks [1]. Dalam melakukan pemetaan cluster akan digunakan algoritma clustering dalam melakukan pembagian kelompok aduan. Algoritma clustering yang cukup popular dalam melakukan pengelompokan objek data salah satunya adalah algoritma kmeans [2],[3],[4]. Pemetaan klaster didasarkan pada organisasi pemerintah daerah yang ada tersebut. Evaluasi hasil cluster dilakukan dengan menggunakan purity untuk mengetahui ketepatan hasil pengelompokkan atau clustering dari data aduan.

\section{Metodologi Penelitian}

Pengumpulan data diperoleh dengan melakukan crawling data aduan masyarakat dari twitter dengan menggunakan kata kunci "laporhendi". Data tersebut dianalisis dengan text mining mengingat data tersebut merupakan data text. Analisis text ini diawali dengan melakukan preprocessing terhadap data mentah hasil crawling data. Tahapan cleansing data dilakukan untuk membersihkan data terhadap duplikasi ataupun dokumen yang sama sekali tidak bermakna, berikutnya adalah melakukan case folding, tokenizing, stopword removal, dan stemming. Hasil preprocessing diperoleh dataset yang siap untuk proses pembobotan term dengan model TF IDF

TRANSFORMATIKA Vol.18, No.2, January 2021 : $215-224$ 
yang dinotasikan dengan nilai 0 dan 1 . Barulah kemudian dilakukan klasterisasi data dengan algoritma k-means. Hasil klaster yang diperoleh akan dievaluasi dengan metode purity untuk mengetahui hasil cluster yang paling optimal.

\subsection{Text Preprocessing}

Pemrosesan awal untuk pengolahan data adalah untuk melakukan pembersihan terhadap data mentah yaitu data text aduan, dengan tahapan sebagai berikut :

\subsubsection{Case folding}

Transformasi terhadap format data text yang ada yaitu dengan mengubah huruf capital menjadi huruf kecil. Selain itu juga melakukan penghapusan terhadap konten dalam text yang bukan karakter. Berikut adalah contoh dokumen atau data tweet yang diproses.

\# LaporHendi tiga hari ini depan Lawang Sewu macet mobil pengunjung berhenti di pinggir jalan. Kalau ada @ satpolpp_smg \&@Dishubkotasmg tertib laporhendi tiga hari ini depan lawang sewu macet mobil pengunjung berhenti di pinggir jalan kalau ada satpolppsmg dishubkotasmg tertib

Gambar 1. Contoh hasil proses case folding

\subsubsection{Tokenizing}

Berikutnya adalah membentuk struktur data text menjadi suatu kata untuk mewakili keseluruhan objek data text. Dimana sebelumnya data dengan struktur kalimat akan dipecah dalam kata per kata.

laporhendi tiga hari ini depan lawang sewu macet mobil pengunjung berhenti di pinggir jalan kalau ada satpolppsmg dishubkotasmg tertib

\begin{tabular}{|l|l|}
\hline laporhendi & berhenti \\
\hline tiga & di \\
\hline hari & pinggir \\
\hline ini & jalan \\
\hline depan & kalau \\
\hline lawang & ada \\
\hline sewu & satpolppsm \\
\hline mobil & dishubkotasmg \\
\hline pengunjung & tertib \\
\hline
\end{tabular}

Gambar 2. Contoh hasil proses tokenizing

\subsubsection{Stopword Removal}

Tahap stopword removal ini adalah menghapus kata atau term yang tidak memberikan makna seperti kata hubung, misalnya "dengan", "atau", dan lain sebagainya. Untuk proses penghapusan kata- kata atau term adalah dengan mengikuti daftar kata yang ada pada daftar stopword. Untuk stopword yang digunakan, penelitian ini memanfaatkan library satrawi.

\subsubsection{Stemming}

Untuk mendapatkan term ahir, maka proses dilanjutkan dengan transformasi tiap kata ke dalam bentuk kata dasar, sehingga berbagai bentuk imbuhan akan dihilangkan.

\subsection{Pembobotan Kata}

Untuk pembentukan vector dari data text, model pembobotan Term Frequency - Inverse Document Frequency (TF-IDF) digunakan dalam penelitian ini dengan menggunakan persamaan berikut [5]. 


$$
W d t=t f d t * I d f t
$$

yaitu dimana :

Wdt $=$ bobot dokumen ke $-d$ terhadap kata ke $-t$

$\mathrm{tfdt}=$ banyaknya kata yang dicari pada sebuah dokumen

$\mathrm{Idft}=$ inversed dokumen frequency $\left(\left(\log \frac{N}{d f}\right)\right)$

$\mathrm{N}=$ total dokumen

$\mathrm{df}=$ banyak dokumen yang mengandung kata yang dicari

\subsection{Clustering}

Algoritma K-Means adalah salah satu algoritma clustering tanpa adanya supervisi (unsupervised). Suatu metode dalam melakukan pengelompokkan dengan menggunakan sistem partisi. Prinsip yang digunakan dari algoritma K-Means ialah mengelompokkan data berdasarkan ke beberapa cluster yang telah ditentukan. Tahapan dalam penghitungan algoritma K-Means adalah sebagai berikut [6], [7], [8],[9]:

1. Tentukan banyak cluster yang akan dibentuk

2. Menentukan nilai pusat cluster awal atau titik centroid

3. Menghitung jarak tiap data yang ada ke centroid yang akan diklaster. Perhitungan jarak ini menggunakan rumus Eucledian Distance. Berikut persamaan Eucledian Distance:

$$
d\left(x_{i}, \mu_{i}\right)=\sqrt{\left(x_{i}-\mu_{i}\right)^{2}}
$$

Keterangan :

$\mathrm{d}\left(x_{i}, \mu_{i}\right) \quad$ : Jarak antara cluster $\mathrm{x}$ dengan pusat cluster $\mu$ pada kata ke $\mathrm{i}$

$x_{i} \quad$ : bobot data ke i pada cluster yang ingin dicari jaraknya.

$\mu_{i} \quad$ : bobot kata ke i pada pusat cluster.

4. Mengelompokkan tiap data ke dalam cluster berdasarkan jarak terdekat dengan centroid

5. Menentukan nilai centroid yang baru

6. Mengulang langkah 2 hingga 3 sampai anggota tiap cluster tidak ada yang berubah

7. Jika anggota cluster tidak berubah, maka nilai rata-rata centroid pada iterasi terakhir digunakan sebagai parameter untuk klasterisasi data.

\subsection{Evaluasi}

Evaluasi hasil kluster dilakukan menggunakan pengukuran purity. Nilai rasio purity ini merupakan nilai dari dokumen text yang di kelompokkan dengan tepat terhadap jumlah seluruh kasus [10]. Rentan nilai rasio tersebut adalah 0 hingga 1 . Jika nilainya mendekati 1 diartikan bahwa sejumlah dokumen yang dikelompokkan benar. Akan tetapi kondisi sebaliknya yaitu apabila nilai rasio mendekati 0 artinya justru semakin kecil dokumen yang dikelompokkan dengan benar. U ntuk menghitung nilai purity menggunakan persamaan sebagai berikut [7] :

$$
\operatorname{Purity}(j)=\frac{1}{n_{j}} \max \left(n_{i j}\right)
$$

Total nilai Purity dapat dihitung dengan rumus berikut :

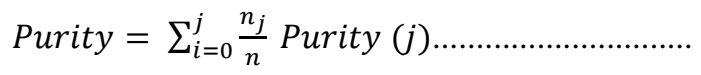

TRANSFORMATIKA Vol.18, No.2, January 2021 : $215-224$ 


\section{Hasil dan Pembahasan}

Data sample yang diolah dalam penelitian ini disajikan dalam Tabel 1 berikut ini. Disajikan 5 sample data atau dokumen yang akan dikelompokkan ke dalam 3 cluster nantinya. Data berikut sudah melalui tahapan preprocessing data.

Tabel 1. Data Sample Aduan Masyarakat

\begin{tabular}{|c|c|c|}
\hline \multirow{5}{*}{ D1 } & Case Folding & $\begin{array}{l}@ \text { pln_123 listrik di wil.kel.sambiroto kec.tembalang kota semarang } \\
\text { sore ini padam. ada apa?? \#laporhendi }\end{array}$ \\
\hline & Cleansing & $\begin{array}{l}\text { listrik di wil kel sambiroto kec tembalang kota semarang sore ini } \\
\text { padam ada apa }\end{array}$ \\
\hline & Tokenizing & $\begin{array}{l}\text { listrik di wil kel sambiroto kec tembalang kota semarang sore ini } \\
\text { padam ada apa }\end{array}$ \\
\hline & Stopwords & listrik wil kel sambiroto kec tembalang kota semarang sore padam \\
\hline & Stemming & $\begin{array}{l}\text { listrik wilayah kelurahan sambiroto kecamatan tembalang kota } \\
\text { semarang sore padam }\end{array}$ \\
\hline \multirow{5}{*}{ D2 } & Case Folding & $\begin{array}{l}\text { \#laporhendi } 3 \text { hari ini depan lawang sewu macet mobil pengunjung } \\
\text { berhenti di pinggir jalan. kalau ada @satpolpp_smg \& } \\
\text { @Dishubkotasmg tertib }\end{array}$ \\
\hline & Cleansing & $\begin{array}{l}\text { hari ini depan lawang sewu macet mobil pengunjung berhenti di } \\
\text { pinggir jalan kalau ada tertib }\end{array}$ \\
\hline & Tokenizing & $\begin{array}{l}\text { hari ini depan lawang sewu macet mobil pengunjung berhenti di } \\
\text { pinggir jalan kalau ada tertib }\end{array}$ \\
\hline & Stopwords & lawang sewu macet mobil pengunjung berhenti pinggir jalan tertib \\
\hline & Stemming & lawang sewu macet mobil kunjung henti pinggir jalan tertib \\
\hline \multirow{5}{*}{ D3 } & Case Folding & $\begin{array}{l}\text { @ hendrarprihadi \#laporhendi air pdam seminggu ini tak mengalir di } \\
\text { perumnas sendang mulyo, gimana ini pak wali..? }\end{array}$ \\
\hline & Cleansing & $\begin{array}{l}\text { air pdam seminggu ini tak mengalir di perumnas sendang mulyo } \\
\text { gimana ini pak wali }\end{array}$ \\
\hline & Tokenizing & $\begin{array}{l}\text { air pdam seminggu ini tak mengalir di perumnas sendang mulyo } \\
\text { gimana ini pak wali }\end{array}$ \\
\hline & Stopwords & air pdam minggu mengalir perumnas sendang mulyo \\
\hline & Stemming & air pdam minggu alir perumnas sendang mulyo \\
\hline \multirow{5}{*}{ D4 } & Case Folding & $\begin{array}{l}\text { \#laporhendi \pdam di wilayah manyaran kp hollywood, hari ini air mati } \\
\text { seharian, ini knp ada giliran atau kerusakan?\@pdamkotasmg } \\
\text { @ hendrarprihadi@p3mkotasmg }\end{array}$ \\
\hline & Cleansing & $\begin{array}{l}\text { pdam di wilayah manyaran kp hollywood hari ini air mati seharian ini } \\
\text { knp ada giliran atau kerusakan }\end{array}$ \\
\hline & Tokenizing & $\begin{array}{l}\text { pdam di wilayah manyaran kp hollywood hari ini air mati seharian ini } \\
\text { knp ada giliran atau kerusakan }\end{array}$ \\
\hline & Stopwords & pdam wilayah manyaran kp hollywood air mati giliran kerusakan \\
\hline & Stemming & pdam wilayah manyaran kp hollywood air mati gilir rusak \\
\hline \multirow{5}{*}{ D5 } & Case Folding & $\begin{array}{l}\text { \#laporhendi @ hendrarprihadi @Dishubkotasmg jalanan } \\
\text { memprihatinkan,,, jati ngaleh macet parah,,, mobil pada mogok. }\end{array}$ \\
\hline & Cleansing & jalanan memprihatinkan jati ngaleh macet parah mobil pada mogok \\
\hline & Tokenizing & jalanan memprihatinkan jati ngaleh macet parah mobil pada mogok \\
\hline & Stopwords & jalanan memprihatinkan jati ngaleh macet parah mobil mogok \\
\hline & Stemming & jalan prihatin jati ngaleh macet parah mobil mogok \\
\hline
\end{tabular}




\subsection{Pembobotan Kata}

Dari data pada Tabel 1, dilakukan pembobotan kata dengan TF-IDF dan diperoleh 37 term dari 5 dokumen text aduan. Hasil perhitungan pembobotan TF-IDF disajikan dalam Tabel 2 berikut ini.

Tabel 2. Pembobotan Term dari Data Sample

\begin{tabular}{|c|c|c|c|c|c|c|c|c|c|c|c|c|}
\hline \multirow{2}{*}{ Term } & \multicolumn{6}{|c|}{ tf } & \multirow{2}{*}{$\frac{\text { idf }}{\log (\text { Dn/df })}$} & \multicolumn{5}{|c|}{$W=\mathbf{t f} * \mathbf{i d f}$} \\
\hline & D1 & D2 & D3 & D4 & D5 & df & & D1 & D2 & D3 & D4 & D5 \\
\hline Listrik & 1 & 0 & 0 & 0 & 0 & 1 & 0,6990 & 0,6990 & 0 & 0 & 0 & 0 \\
\hline Wilayah & 1 & 0 & 0 & 1 & 0 & 2 & 0,3979 & 0,3979 & 0 & 0 & 0,3979 & 0 \\
\hline Kelurahan & 1 & 0 & 0 & 0 & 0 & 1 & 0,6990 & 0,6990 & 0 & 0 & 0 & 0 \\
\hline sambiroto & 1 & 0 & 0 & 0 & 0 & 1 & 0,6990 & 0,6990 & 0 & 0 & 0 & 0 \\
\hline kecamatan & 1 & 0 & 0 & 0 & 0 & 1 & 0,6990 & 0,6990 & 0 & 0 & 0 & 0 \\
\hline tembalang & 1 & 0 & 0 & 0 & 0 & 1 & 0,6990 & 0,6990 & 0 & 0 & 0 & 0 \\
\hline Kota & 1 & 0 & 0 & 0 & 0 & 1 & 0,6990 & 0,6990 & 0 & 0 & 0 & 0 \\
\hline Semarang & 1 & 0 & 0 & 0 & 0 & 1 & 0,6990 & 0,6990 & 0 & 0 & 0 & 0 \\
\hline Sore & 1 & 0 & 0 & 0 & 0 & 1 & 0,6990 & 0,6990 & 0 & 0 & 0 & 0 \\
\hline Padam & 1 & 0 & 0 & 0 & 0 & 1 & 0,6990 & 0,6990 & 0 & 0 & 0 & 0 \\
\hline Lawang & 0 & 1 & 0 & 0 & 0 & 1 & 0,6990 & 0 & 0,6990 & 0 & 0 & 0 \\
\hline Sewu & 0 & 1 & 0 & 0 & 0 & 1 & 0,6990 & 0 & 0,6990 & 0 & 0 & 0 \\
\hline Macet & 0 & 1 & 0 & 0 & 1 & 2 & 0,3979 & 0 & 0,3979 & 0 & 0 & 0,3979 \\
\hline Mobil & 0 & 1 & 0 & 0 & 1 & 2 & 0,3979 & 0 & 0,3979 & 0 & 0 & 0,3979 \\
\hline Kunjung & 0 & 1 & 0 & 0 & 0 & 1 & 0,6990 & 0 & 0,6990 & 0 & 0 & 0 \\
\hline Henti & 0 & 1 & 0 & 0 & 0 & 1 & 0,6990 & 0 & 0,6990 & 0 & 0 & 0 \\
\hline Pinggir & 0 & 1 & 0 & 0 & 0 & 1 & 0,6990 & 0 & 0,6990 & 0 & 0 & 0 \\
\hline Jalan & 0 & 1 & 0 & 0 & 1 & 2 & 0,3979 & 0 & 0,3979 & 0 & 0 & 0,3979 \\
\hline Tertib & 0 & 1 & 0 & 0 & 0 & 1 & 0,6990 & 0 & 0,6990 & 0 & 0 & 0 \\
\hline Air & 0 & 0 & 1 & 1 & 0 & 2 & 0,3979 & 0 & 0 & 0,3979 & 0,3979 & 0 \\
\hline Pdam & 0 & 0 & 1 & 1 & 0 & 2 & 0,3979 & 0 & 0 & 0,3979 & 0,3979 & 0 \\
\hline Minggu & 0 & 0 & 1 & 0 & 0 & 1 & 0,6990 & 0 & 0 & 0,6990 & 0 & 0 \\
\hline Alir & 0 & 0 & 1 & 0 & 0 & 1 & 0,6990 & 0 & 0 & 0,6990 & 0 & 0 \\
\hline Perumnas & 0 & 0 & 1 & 0 & 0 & 1 & 0,6990 & 0 & 0 & 0,6990 & 0 & 0 \\
\hline Sendang & 0 & 0 & 1 & 0 & 0 & 1 & 0,6990 & 0 & 0 & 0,6990 & 0 & 0 \\
\hline Mulyo & 0 & 0 & 1 & 0 & 0 & 1 & 0,6990 & 0 & 0 & 0,6990 & 0 & 0 \\
\hline Manyaran & 0 & 0 & 0 & 1 & 0 & 1 & 0,6990 & 0 & 0 & 0 & 0,6990 & 0 \\
\hline $\mathrm{Kp}$ & 0 & 0 & 0 & 1 & 0 & 1 & 0,6990 & 0 & 0 & 0 & 0,6990 & 0 \\
\hline hollywood & 0 & 0 & 0 & 1 & 0 & 1 & 0,6990 & 0 & 0 & 0 & 0,6990 & 0 \\
\hline Mati & 0 & 0 & 0 & 1 & 0 & 1 & 0,6990 & 0 & 0 & 0 & 0,6990 & 0 \\
\hline Gilir & 0 & 0 & 0 & 1 & 0 & 1 & 0,6990 & 0 & 0 & 0 & 0,6990 & 0 \\
\hline Rusak & 0 & 0 & 0 & 1 & 0 & 1 & 0,6990 & 0 & 0 & 0 & 0,6990 & 0 \\
\hline
\end{tabular}

TRANSFORMATIKA Vol.18, No.2, January 2021: 215-224 


\begin{tabular}{l|c|c|c|c|c|c|c|c|c|c|c|c}
\hline Prihatin & 0 & 0 & 0 & 0 & 1 & 1 & 0,6990 & 0 & 0 & 0 & 0 & 0,6990 \\
\hline Jati & 0 & 0 & 0 & 0 & 1 & 1 & 0,6990 & 0 & 0 & 0 & 0 & 0,6990 \\
\hline Ngaleh & 0 & 0 & 0 & 0 & 1 & 1 & 0,6990 & 0 & 0 & 0 & 0 & 0,6990 \\
\hline Parah & 0 & 0 & 0 & 0 & 1 & 1 & 0,6990 & 0 & 0 & 0 & 0 & 0,6990 \\
\hline Mogok & 0 & 0 & 0 & 0 & 1 & 1 & 0,6990 & 0 & 0 & 0 & 0 & 0,6990 \\
\hline
\end{tabular}

\subsection{Clustering dengan Algoritma K-means}

Sebagai langkah awal dalam clustering yaitu perlu ditentukan titik pusat awal atau titik centroid awal. Tabel 3 berikut menjadi centroid awal yang dipilih secara acak yang diambil dari dokumen term :

Tabel 3. Titik centroid

\begin{tabular}{c}
\hline Nilai Titik Awal Cluster (centroid) \\
\hline C1 $=$ D5 \\
\hline C $2=\mathrm{D} 1$ \\
\hline $\mathrm{C} 3=\mathrm{D} 3$ \\
\hline
\end{tabular}

Selanjutnya dilakukan perhitungan jarak tiap data dengan titik pusat klaster awal yang sudah ditentukan. Dengan menggunakan fungsi eucledian distance dihitung jarak ttiap data ersebut ke masing-masing titik pusat dengan hasil disajikan pada Tabel 4 sebagai berikut :

Tabel 4. Hasil perhitungan jarak eucledian distance iterasi 1

\begin{tabular}{c|c|c|c|c|c}
\hline \multirow{2}{*}{ Centroid } & \multicolumn{5}{|c}{ Jarak ke centroid } \\
\cline { 2 - 6 } C1 & D1 & D2 & D3 & D4 & D5 \\
\hline C2 & 0 & 2,3182 & 2,3827 & 2,5148 & 0 \\
\hline C3 & 2,7046 & 2,4831 & 0 & 2,35217 & 2,3827 \\
\hline
\end{tabular}

Setelah diperoleh jarak antar centroid dengan data maka ditentukan jarak yang paling dekat dari setiap data dengan centroid. Yang nantinya jarak terdekat merupakan kelompok data pada cluster tersebut. Berikut kelompok anggota cluster pada iterasi 1 :

Tabel 5. Pengelompokan anggota cluster iterasi 1

\begin{tabular}{c|c|c|c|c|c}
\hline \multicolumn{5}{c}{ Pengelompokan anggota cluster Iterasi 1 } \\
\hline & D1 & D2 & D3 & D4 & D5 \\
\hline C1 & 2,7337 & 2,3182 & 2,3827 & 2,5148 & 0 \\
\hline C2 & 0 & 2,8217 & 2,7046 & 2,7650 & 2,7337 \\
\hline C3 & 2,7046 & 2,4831 & 0 & 2,3521 & 2,3827 \\
\hline
\end{tabular}

Berikutnya dilakukan perhitungan jarak tiap dokumen ke titik centroid baru dan menghasilkan anggota cluster seperti pada Tabel 6 berikut.

Aplikasi Text Mining untuk Klasteisasi Aduan Masyarakat Kota Semarang Menggunakan Algoritma K-Means (Dita Afida) 
Tabel 6. Hasil jarak tiap data pada iterasi 2

\begin{tabular}{c|c|c|c|c|c}
\hline \multicolumn{6}{c}{ Pengelompokan anggota cluster Iterasi 2 } \\
\hline & D1 & D2 & D3 & D4 & D5 \\
\hline C1 & 2,5247 & 1,1591 & 2,1397 & 2,2858 & 1,1591 \\
\hline C2 & 0 & 2,8217 & 2,7046 & 2,7650 & 2,7337 \\
\hline C3 & 2,4692 & 2,5297 & 1,1761 & 1,1761 & 2,1489 \\
\hline
\end{tabular}

Pada iterasi kedua, didapati bahwa anggota klaster tidak mengalami perubahan sehingga proses perhitungan jarak berhenti dan diperoleh hasil ahir anggota klaster sebagai berikut.

\subsection{Evaluasi Hasil Klaster}

Sedangkan untuk menghitung nilai purity setiap cluster pada hasil perhitungan data diatas dengan jumlah 5 Data dan 3 Cluster sebagai berikut :

Tabel 7. Hasil evalusi cluster dengan purity

\begin{tabular}{c|c|c|c|c|c}
\hline Cluster & Jumlah & PLN & PDAM & Dishub & Purity \\
\hline C1 & 2 & 0 & 0 & 2 & 1 \\
\hline C2 & 1 & 1 & 0 & 0 & 1 \\
\hline C3 & 2 & 0 & 2 & 0 & 1 \\
\hline Total & 5 & & & & \\
\hline \multicolumn{7}{|r}{}
\end{tabular}

Dari evaluasi hasil cluster tersebut diperoleh nilai purity untuk 3 cluster dengan 5 data sample adalah sebesar 1. Sehingga hasil evaluasi pada data sample yang digunakan memiliki hasil yang baik karena bernilai 1, artinya setiap data masuk ke cluster yang sesuai dengan tepat. Untuk selanjutnya model cluster akan dibangun dari sejumlah data yang sudah diperoleh dari proses crawling data pada twitter.

\subsection{Dashboard Aplikasi Klastering Aduan Masyarakat}

Model dari hasil analisis cluster untuk data aduan menggunakan algoritma k-means selanjutnya diimplementasikan ke dalam prototype dari aplikasi analisis text aduan masyarakat. Hasil dari clustering data yang telah diinputkan yaitu terbagi menjadi 11 OPD yang ada dan menjadi acuan banyaknya jumlah cluster yang dibentuk. Aplikasi akan menampilkan data aduan yang masuk kemudian mengkategorikan setiap aduan tersebut ke masing- masing unit atau dalam hal ini OPD yang sesuai. Aplikasi analisis text aduan masyarakat yang dikembangkan disajikan dalam Gambar 3 berikut ini. Secara keseluruhan, data yang dikumpulkan dan dianalis adalah sejumlah 1171 data aduan.

Pada Gambar 3, aplikasi menampilkan data aduan yang masuk dan kemudian memberikan keterangan hasil clusternya. Sehingga aplikasi analisis text aduan masyarakat ini akan secara otomatis mengelompokkan cluster setiap aduan yang masuk. Petugas terkait tidak lagi kesulitan dalam membaca maupun mengelompokkan aduan yang masuk karena sistem sudah secara langsung mengelompokkan. Harapannya dari aplikasi yang dirancang ini maka dapat membantu petugas mempercepat proses tindak lanjut aduan ke OPD terkait. Yang pada ahirnya tentu dapat meningkatkan layanan pemerintah kepada masyarakat.

TRANSFORMATIKA Vol.18, No.2, January 2021 : $215-224$ 


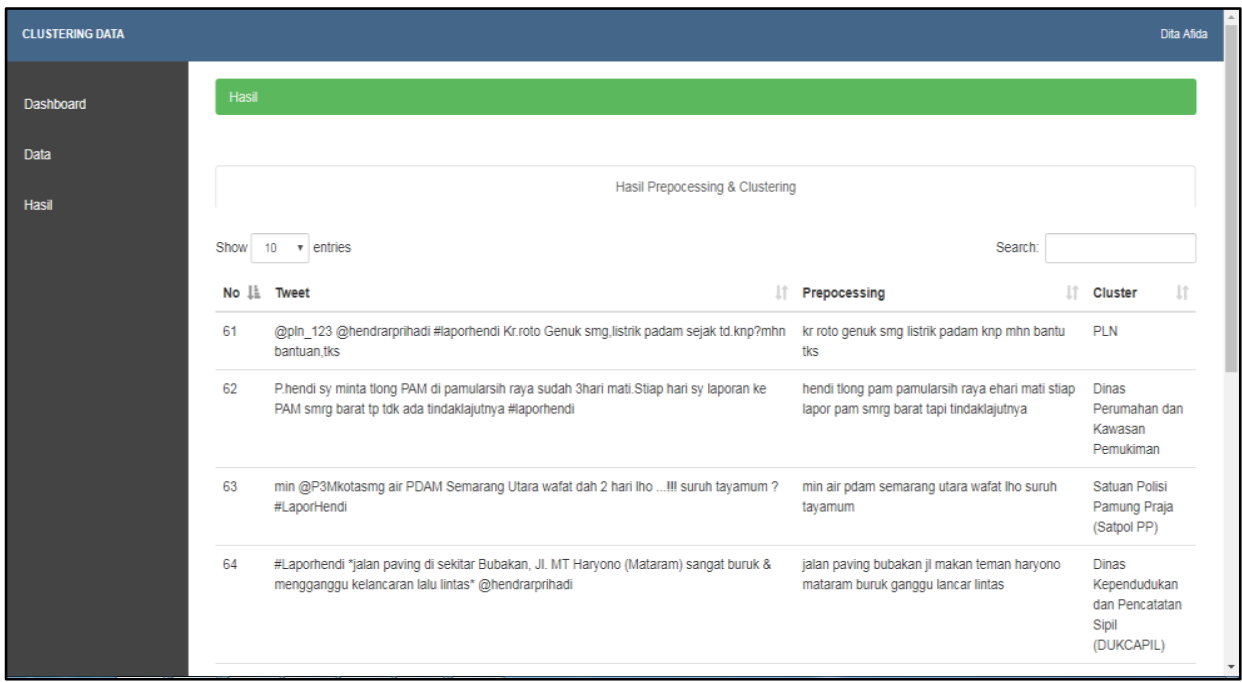

Gambar 3. Dashboard hasil klastering

Pada Gambar 4 dibawah ini adalah merupakan tampilan dashboard untuk keseluruhan data yang telah di kelompokkan ke dalam berbagai cluster atau OPD yang ada. Nampak bahwa aplikasi memberikan informasi total aduan masyarakat yang masuk untuk setiap cluster.

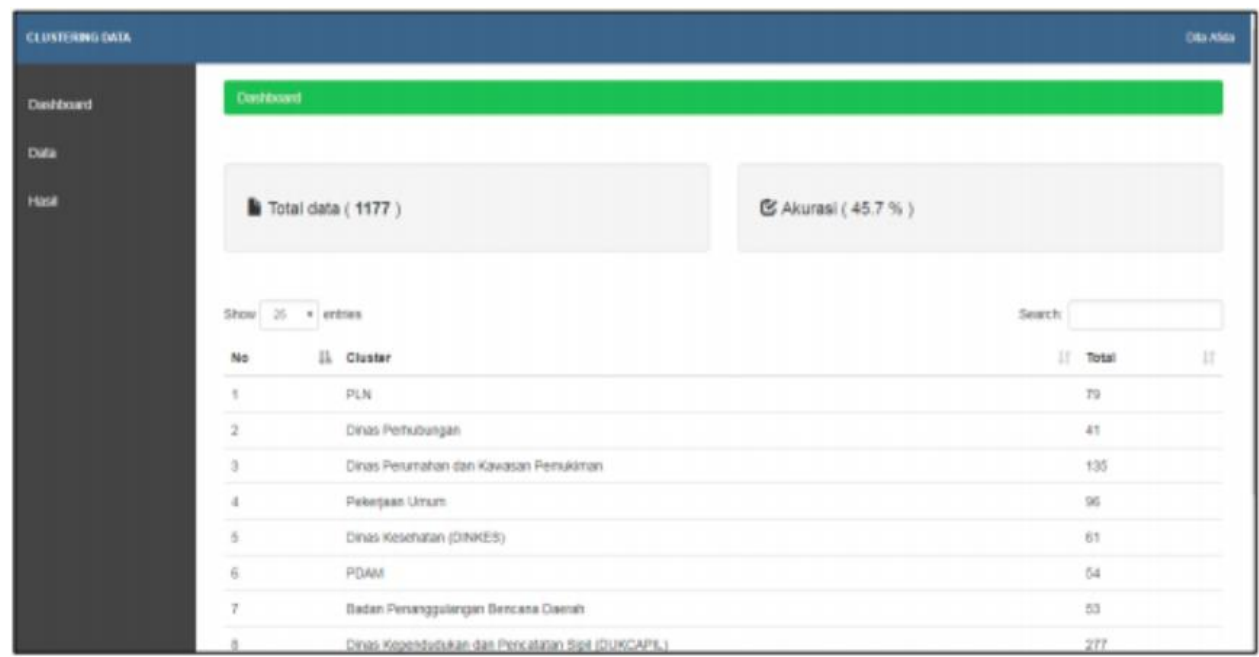

Gambar 4. Dashboard total aduan yang dikelompokkan ke setiap cluster

\section{Kesimpulan}

Dari hasil analisis text mining yang telah dilakukan pada data text aduan masyarakat yang bersumber dari twitter. Dapat disimpulkan bahwa hasil pengelompokkan (cluster) data dengan algoritma k-means mendapatkan hasil yang bagus. Hal ini didapat dari nilai purity yang mana nilainya adalah 1 untuk tiap cluster yang ada. Oleh karena itu dalam melakukan klasterisasi text aduan masyarakat dapat memanfaatkan algoritma k-means. Dan model cluster yang diterapkan dalam aplikasi analisis text aduan masyarakat dapat membantu pihak terkait dalam proses otomatisasi pengelompokkan aduan masyarakat ke dinas terkait. Sehingga proses tindak lanjut aduan menjadi lebik efektif. 


\section{References}

[1] M. Afzali and S. Kumar, "Text Document Clustering: Issues and Challenges," 2019 Int. Conf. Mach. Learn. Big Data, Cloud Parallel Comput., pp. 263-268, 2019.

[2] X. et al Wu, "Top 10 algorithms in data mining," Knowl. Inf. Syst., vol. 14, pp. 1-37, 2008.

[3] S. Karyadi and H. Yasin, "Analisis Kecenderungan Informasi Dengan Menggunakan Metode Text Mining," J. Gaussian, vol. 5, pp. 763-770, 2016.

[4] D. S. Indraloka, B. Santosa, D. Matematika, F. Matematka, P. Alam, I. Teknologi, and S. Nopember, "Penerapan Text Mining untuk Melakukan Clustering Data Tweet Shopee Indonesia," J. Sains dan Seni, vol. 6, no. 2, pp. 6-11, 2017.

[5] R. Melita, V. Amrizal, H. B. Suseno, T. Dirjam, P. Studi, T. Informatika, and F. Sains, "Penerapan Metode Term Frequency Inverse Document Frequency (Tf-Idf) Dan Cosine Similarity Pada Sistem Temu Kembali Informasi Untuk Mengetahui Syarah Hadits Berbasis Web ( Studi Kasus : Syarah Umdatil Ahkam )," J. Tek. Inform., vol. 11, no. 2, 2018.

[6] R. K. Dinata, N. Hasdyna, and N. Azizah, "Analisis K-Means Clustering pada Data Sepeda Motor," Informatics J., vol. 5, no. 1, 2020.

[7] J. Teknik, I. Fik, and J. N. N. Semarang-, "Klasterisasi Proses Seleksi Pemain Menggunakan Algoritma K-Means," Universitas Dian Nuswantoro, 2015.

[8] S. Defiyanti, M. Jajuli, T. Informatika, F. Ilmu, K. Universitas, and S. Karawang, "Implementasi Algoritma K-Means Dalam," J. Ilm. Inf. Terap., vol. I, no. 2, pp. 62-68, 2015.

[9] A. K. Wardhani, "Implementasi Algoritma K-Means Untuk Pengelompokkan Penyakit Pasien Pada Puskesmas Kajen Pekalongan," J. Transform., vol. 14, pp. 30-37, 2016.

[10] K. R. Prilianti and K. Kunci, "Aplikasi Text Mining untuk Automasi Penentuan Tren Topik Skripsi dengan Metode K-Means Clustering," J. Cybermatika, vol. 2, no. 1, pp. 1-6, 2014. 